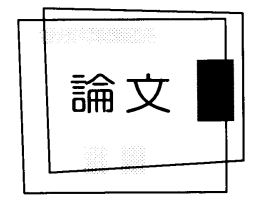

\title{
ケミカルタンカーにおけるベンゼン輸送中の 環境濃度とそのリスク*
}

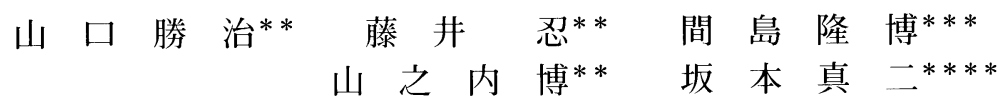

Workplace Concentration of Benzene Vapor during Marine Transfer Operations and Its Risk

By Katsuji Yamaguchi, Sinobu Fujii, Takahiro Majima,

Hiroshi Yamanouchi, Shinji Sakamoto

International Maritime Organization(IMO) recognized that chronic exposure to very low concentration of benzene vapor in air of the order of a few parts per million may cause cancer.

It is necessary to protect the health of sailors exposed to benzene vapor to the same level as that of shorebased workers performing compatible tasks.

Measurements of onboard environment benzene vapor concentration for tankers carrying benzene during loading, transit, unloading and tank cleaning operations of routine tanker operation were made during all seasons of the year for typical size of 500 tons and 1000 tons cargoes.

The vapor samples were collected from 11 tankers in 3 points on the ship to the canister and were subsequently analized by gas chromatography. The benzene vapor concentrations were varied with operations and onboard points.

The risk of health of sailors exposed to benzene vapor is assessed using time and area averaged concentration. Effectiveness of wearing respiratory equipment for reducing health risk of sailors due to benzene exposure during marine vessel transfer operations is suggested.

\section{1.はじめに}

化学物質は我々の生活に欠かせないものとなっ て抒り，多くの化学物質が海上輸送されている. 有用な化学物質も輸送中の管理の仕方によっては 人の健康や生態系に有害な影響を及ぼすおそれが ある.

液体化学物質の海上輸送中の安全や環境への影 響に関しては，これまで漏洩ガスによる爆発の危 険性や大量曝露による急性毒性の問題として取り 組まれ, 長期, 微量曝露による健康影響に焦点が

*原稿受付 平成 12 年 1 月 14 日

**正会員 船舶技術研究所 (三鷹市新川6-38-1)

***船舶技術研究所 (三鷹市新川6-38-1)

$* * * *$ 海上保安庁 (千代田区霞が関2-1-3)
あてられたことはほとんどなかった。しかし，化 学物質の微量曝露, 長期曝露による健康影響は遅 れて現出するため, 影響が顕在化してから対策に 取り組むのでは手遅れとなる。従って, 予防的観 点から実態を把握し, 有害揮発性化学物質の海上 輸送に従事する乗組員のみならず，岸壁での荷役 従事者打よび周辺住民へのガス曝露による健康被 害を防止するための対策を構築する必要がある.

ベンゼンは化学製品の基礎材料として幅広く使 われるため大量に生産され，生産地から消費地へ 大量に海上輸送されている。海上輸送は比較的小 型の内航ケミカルタンカーによって行われており， 通常500トンまたは1000トン単位で輸送される. このため, 大量の純ベンゼンが頻繁に海上輸送さ れることになり, 輸送作業に従事する乗組員や荷 役従事者, 荷役検查従事者のベンゼンを取り扱う 
機会は多くなっている，岸壁での荷役作業中及び 海上輸送中に蒸発しガスとなって，船舶から大気 中に漏出・排出され, 移流・拡散して大気を污染 するが (1), 低濃度のベンゼンガスでも乗組員及び 荷役従事者等が慢性的に曝露されると白血病の原 因になりうると懸念されている。

本報告では有害揮発性化学物質である純ベンゼ ンをとりあげ，ベンゼンを輸送している船舶の通 常積み荷役時, 航海中, 揚げ荷役時およびタンク クリーニング時に, 甲板上, ポンプ室及び居住区 域で, 健康被害防止の観点から環境中の微小なべ ンゼンガス濃度を測定し, それらのデータを用い て, ベンゼン輸送作業従事中の乗組員へのベンゼ ンガス曝露による健康影響の大きさを, リスクか ら評価した結果，について述べる.

\section{2. 化学物質海上輸送の実態}

\section{1 輸送の実情}

1997年, 国内で海上輸送された液体化学物質は 約 230 品目で, 年間 1 万トン以上は約 90 品目, 10 万 トン以上はキシレン, スチレン, ベンゼン, 1,2-ジ クロロエタン，アクリロニトリル，トルエン等の 健康に有害な影響を及ぼす物質を含む 26 品目であ

表 1 ガス排出場所

\begin{tabular}{|c|c|c|}
\hline 作業形態 & 発生機構 & 排出場所 \\
\hline \multirow[t]{3}{*}{ 積み荷役 } & 皘み荷からの蒸発 & ベント管出口 \\
\hline & 洏洩液からの蒸発 & $\begin{array}{l}\text { ローディングアーム } \\
\text { 接絰部 }\end{array}$ \\
\hline & シール部等からの償油 & 并、フランジ部等 \\
\hline \multirow[t]{2}{*}{ 航海 } & 盉み荷からの蒸発 & ベント管出口 \\
\hline & シール部等からの㴋洩 & 井、フランジ部等 \\
\hline \multirow[t]{4}{*}{ 掦げ荷役 } & \begin{tabular}{|l} 
䨛げ該当タンク以外のタンク \\
の積み荷からの蒸発 \\
\end{tabular} & ベント管出ロ \\
\hline & 湍洩液からの蒸発 & $\begin{array}{l}\text { ローデイングアーム } \\
\text { 接統部 }\end{array}$ \\
\hline & 橡み荷からの葖発 & タンクハッチ \\
\hline & シール部等からの晹洩 & ポンプシール部等 \\
\hline \multirow{4}{*}{$\begin{array}{l}\text { タンク } \\
\text { クリーニング }\end{array}$} & 揖げ荷後の㱟液からの蒸発 & ベント管出ロ \\
\hline & 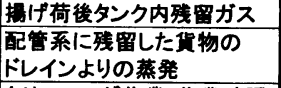 & $\begin{array}{l}\text { タンクハッチ } \\
\text { 甲板上やポンプ室の } \\
\text { ドレイン埥所 }\end{array}$ \\
\hline & クリーニング作虽・作䝴確现 & 賲物タンク内 \\
\hline & $\begin{array}{l}\text { ホンフフ配管系の觬放により } \\
\text { それらへの残液や付符液の } \\
\text { 蒸発 }\end{array}$ & ポンプ配管系 \\
\hline
\end{tabular}

り, 輸送量の約 $90 \%$ が年間 1 万トン以上の約 90 品目 で占められている．液体化学物質を国内輸送する 一般ケミカル船は約 230 隻あり, 輸送によるガス曝 露の可能性のある者は輸送に直接従事する乗組員 と岸壁での荷役作業者, 荷役検査員および工場周 辺住民が含まれる。

\section{2 輸送作業の区分と環境濃度の形成}

揮発性液体化学物質の海上輸送は, 岸壁での 「積み荷作業」および「揚げ荷作業」, 出荷地から 受荷地までの「航海中の作業」, 揚げ荷後, 出荷地 に向かう間に行われる「タンククリーニング作業」 の4つに区分できる作業サイクルを繰り返しながら 行われる. 作業中に揮発性化学物質は蒸発してガ スとなり表1に示す発生源から排出されたガスは空 気中を移流・拡散して船上および周辺の空気を污 染し, 環境濃度が形成される。乗組員は呼吸する ことにより空気中に含まれた化学物質に曝露される.

\section{3 船上での液体化学物質による曝露の特徵}

一般にケミカルタンカーでは, 輸送ごとに貨物 の種類が変わり, 従って輸送ごとに乗組員の曝露 される化学物質の種類が変化する.また一回の輸 送においては貨物の積み込み, 海上輸送, 荷揚げ, タンククリーニングという過程を経るため発生源 の場所や強度が時間的に一定せず, 環境濃度は場 所的にも時間的にも一定しない.

\section{3. 液体化学物質海上輸送中のリスク評価}

\section{1 評価の方法}

液体化学物質を海上輸送することによって生ず る環境への影響を定量的に評価するため, それを リスクとして表現し，リスクを使って船上環境濃 度をどう管理すべきか検討する。

リスク評価は図 1 に示す手順で行った。（1）問 題とその原因物質を特定し, 評価する影響判定点 を決定する。（2）現場調査に基づきモニタリング 方法を決定する。（3）化学物質に曝露される量を モニタリングの結果および排出源情報と拡散情報 に基づいて解析する。（4）化学物質の量と影響の 
定量的関係を評価する。（5）人健康リスクの大き さを算定し，評価する。（6）リスク削減のための 代替案を選択し代替案を評価する。

\section{2 対象物質としてベンゼンを特定}

ベンゼンは化学製品の基礎材料であるため 1995 年には 420 万トンもの大量が生産され，そのうち国 内の海上輸送量は 130 万トンであり，1996年およ び1997年には140万トンが海上輸送されている.

ベンゼンの出荷地及び受荷地は関東以西の太平 洋岸扎よび瀬戸内海地域, 九州地区に幅広く分布 し，工場内の海に面した湾内または内海の岸壁で あり，工場に隣接して民家や一般道がある。海上 輸送には300～500総トンケミカル船が多く使用さ れており，4〜7人の乗組員によって運行されてい る. 岸壁では $2 \sim 3$ 人の作業員が直接荷役作業に従 事する.

ベンゼンは発ガン物質であるため, 厳しい環境 濃度管理が求められており, 作業環境ベンゼン濃 度は通常の陸上の作業者を反映して IMO(国際海事 機関)では 8 時間作業中の平均濃度(TWA) $1 \mathrm{ppm}, 15$ 分間平均濃度 (STEL) $5 \mathrm{ppm}$ を超える場合, 保護具 を装着するよう勧告している。

このようにベンゼンは有害物質であること, 大 量・頻繁に輸送されていること, IMOで濃度管理 が勧告されたこと, 等により海上輸送中の液体化 学物質のリスク評価対象物質としてベンゼンを特 定した。「癌になる危険性」を影響判定点として，

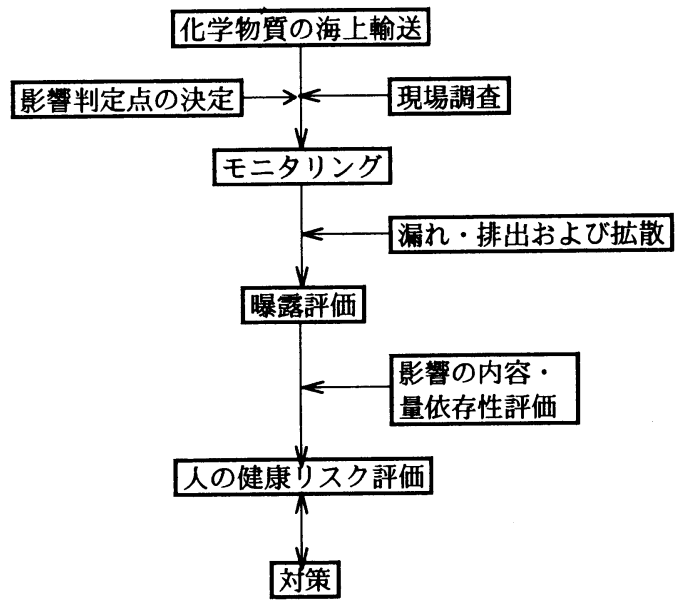

図1リスク評価の手順
ベンゼン環境濃度測定データを用い, ベンゼン輸 送に従事する乗組員に対する健康リスク評価を 行った.

\section{4. 環境濃度計測}

\section{1 測定船舶の概要と計測条件}

測定対象船舶として選定したのは我が国の内航 タンカーのうち, 最も数が多く, よく用いられる 499 総トンおよび399総トンの液体化学薬品バラ積 み船タイプIIIである。航海あたりのベンゼン輸送 量は499GT船では約1000トン，399GT船では約500 トンである。

499GT船（399GT）の全長は63m(52m), 型幅は $10 \mathrm{~m}(9 \mathrm{~m})$ である。な扰，括弧は399GTについての 記述である。機関室および船橋は船尾に位置し， 船橋より前部は貨物タンクとなっている. 船中央 部にベント管, 機関室に隣接してポンプ室が配置 されている. 左右に 2 タンク, 前後に 4 タンク (3タ ンク), 合計 8 タンク(6タンク)を有し, 各タンクの 容積は約 $140(80)$ から約 $180 \mathrm{~m}^{3} \quad\left(140 \mathrm{~m}^{3}\right)$, 合計約 1300(660) $\mathrm{m}^{3}$ である. 左右舷タンクと前後方向タン ク共通, つまり 4 タンク共通の高さ $6 \mathrm{~m}$ のベント管 を2本有している。

499GT輸送船の概要を図2に示す。本研究の測定 対象船, 作業形態, 計測条件を表 2 に示す。 500 卜 ン積み船6隻，1000トン積み船6隻について合計19 ケース測定した。



図2499GT輸送船の概要と計測場所 


\section{2 測定場所}

船内でのベンゼンガスの採取は多くの乗組員が 長時間過ごす場所で行った。乗組員が室内で作業 及び休息する操舵室, 居室及び食堂のある「居住 区域」, ベンゼンの揚げ荷時等に使用され，濃度が 比較的高いと考えられる「ポンプ室」, 荷役作業中 弁操作や貨物監視等の作業が長時間にわたり，作 業がよく行われる甲板上とした。甲板上の代表点 として「ベント管下」を選定した。居住区と同じ 方法で換気が行われている機関室は居住区と同一 区画と考えた。

\section{3 ガス採取方法及び分析方法}

ガスの採取及び分析は環境庁「有害大気污染物 質測定マニュアル」(2) に従って行った.

食堂，操舵室，ポンプ室，ベント管下に，あら かじめ洗浄され, 真空ポンプで $1 \mathrm{mmHg}$ 以下に脱気 された内容積 15 リットルのステンレス製の容器

表2 計測条件と作業形態

\begin{tabular}{|c|c|c|c|c|c|c|}
\hline $\begin{array}{l}\text { 計測 } \\
\text { 船舶 } \\
\text { 番号 }\end{array}$ & \begin{tabular}{|l} 
計 \\
测 \\
月 \\
\end{tabular} & $\begin{array}{l}\text { 総卜 } \\
\text { ン数 } \\
\text { (トン) }\end{array}$ & $\begin{array}{l}\text { 穦載 } \\
\text { 量 } \\
\text { (トン) } \\
\end{array}$ & \begin{tabular}{|c|} 
ガス採 \\
取時間 \\
(分)
\end{tabular} & $\begin{array}{l}\text { 作業 } \\
\text { 形態 }\end{array}$ & $\begin{array}{l}\text { 平均 } \\
\text { 気温 } \\
\left({ }^{\circ} \mathrm{C}\right)\end{array}$ \\
\hline 101 & 5 & 499 & 1000 & 215 & LO & 20 \\
\hline 102 & 7 & 498 & 1000 & 177 & LO & 31 \\
\hline 102 & 7 & 498 & 1000 & 70 & VA & 31 \\
\hline 102 & 7 & 498 & 1000 & 110 & UL & 31 \\
\hline 103 & 2 & 498 & 500 & 94 & LO & 9 \\
\hline 104 & 2 & 498 & 1000 & 185 & LO & 9 \\
\hline 105 & 8 & 499 & 500 & 90 & LO & 30 \\
\hline 105 & 8 & 499 & 500 & 130 & VA & 30 \\
\hline 105 & 8 & 499 & 500 & 110 & UL & 30 \\
\hline 106 & 9 & 263 & 500 & 137 & LO & 30 \\
\hline 106 & 9 & 263 & 500 & 120 & VA & 30 \\
\hline 107 & 11 & 499 & 1000 & 175 & LO & - \\
\hline 108 & 8 & 499 & 1000 & 1770 & VA & 26.5 \\
\hline 109 & 10 & 499 & 500 & 1075 & VA & 23 \\
\hline 109 & 9 & 499 & 1000 & 330 & TC & 23 \\
\hline 110 & 7 & 344 & 500 & 97 & UL & 22.5 \\
\hline 110 & 7 & 344 & 500 & 300 & $\mathrm{TC}$ & 22.5 \\
\hline 111 & 7 & 498 & 500 & 148 & UL & 30 \\
\hline 111 & 7 & 498 & 500 & 180 & $\mathrm{TC}$ & 30 \\
\hline
\end{tabular}

LO:積み荷役 UL:揚げ荷役

VA:航海 TC:タンククリーニング
キャニスターを設置し，作業形態ごとに作業の開 始から終了までの間，一定流量で大気を採取した。 このため採取されたガスは或る場所，或る作業区 分での平均濃度を示すものとなる。採取点の高さ は床から $1 \mathrm{~m} 〜 1.5 \mathrm{~m}$ であった。

採取したガスをガスクロマトグラフ質量法にて 分析し，ガス採取時間内の平均ベンゼンガス濃度 を求めた。

\section{5. 計測結果}

船舶ごと，また「積み荷作業」「航海時の作業」 「揚げ荷作業」「タンククリーニング作業」の作業 形態ごとに，および「居住区」「ポンプ室」「ベン ト管下」の場所ごとに計測した結果を示す。

\section{1 船舶ごとの環境濃度}

船舶ごとに，計測場所をパラメータに，作業形 態に対する環境濃度の測定例を図3に示す。環境 濃度は作業形態ごとに，また計測場所ごとに大き く変化することを示している。場所ごとの作業形 態に対する濃度変化の傾向は一定しておらず，船 舶ごとに異なっている．船舶ごとにまた作業形態 ごとに排出源条件や気象条件が異なることを示し ている.

\section{2 作業形態ごとの環境濃度}

居住区，ポンプ室，ベント管下で作業形態ごと に得られた測定結果を罒4に棒グラフで示す。それ ぞれの棒は一船ごとの測定值を表している.

\subsection{1 積み荷作業中の環境濃度}

ベンゼンは陸上のポンプによって貯蔵タンクか ら船の貨物タンクに，タンク深さの $98 \%$ 程度まで 積み込まれる。積み荷役中, 貨物の蒸発によって タンク内で発生したガスはベント管から排出され る。ポンプ停止後, 積み込み管系に残留したベン ゼンは窒素ガスを用いて陸側より船側に押し込ま れる．岸壁側と船側の接続管が切り離され，この 時，積み込み管系に残った少量のベンゼンが漏れ， 周辺の大気が污染される。積み荷役中に計測され た環境濃度を図4(a)に示す。ガス排出口であるべ 

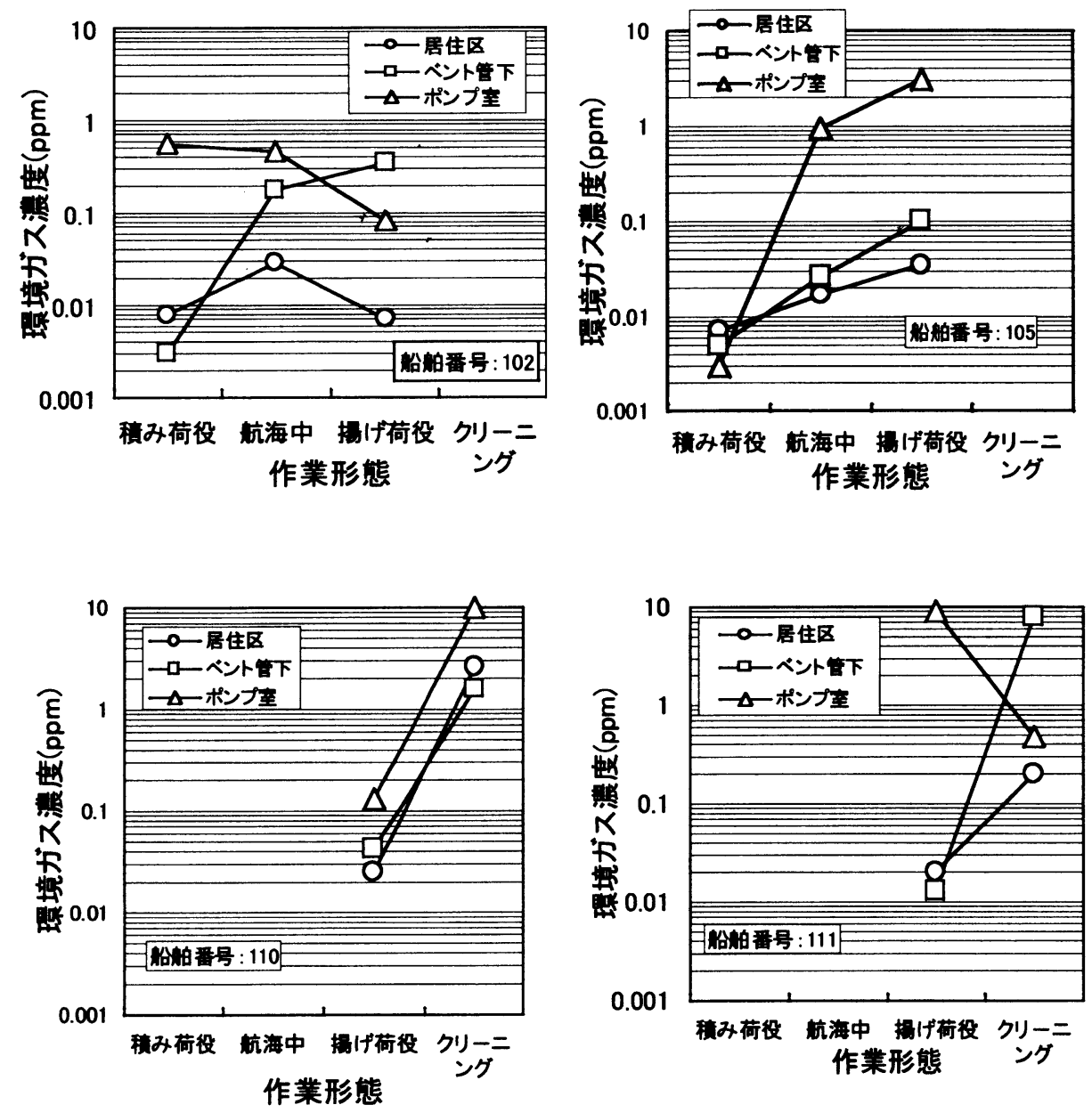

図3船舶ごとの環境濃度

ント管から最も離れている居住区内での值は $0.1 \mathrm{ppm}$ 程度以下と低く，そこより排出源に近いポ ンプ室は多少高い值を示している，バックグラン ドや岸壁のベンゼン濃度は $0.01 \mathrm{ppm}$ 程度かそれ以 下であり，居住区内ではバックグランドよりやや 高い值である。排出源直下のべント管下ではあま り高い濃度ではなく, 荷役中のガスは速度をもっ て排出されることや風速によって，排出ガスの多 くはべント管下に達しないことを示している。

\subsection{2 航海中の環境濃度}

航海時に計測された環境濃度を罒4(b)に示す。 積み地から揚げ地への航海では，貨物タンクは通 常満載であり，航海中，貨物が蒸発することによ り発生したガスがベント管から排出されるか，時
にはタンクに接続されたポンプ, 弁, フランジ等 配管系からのリークによるガスが発生源と考えら れ, 発生源強度は大きくないものの船内に広く分 布している．航海時の環境濃度は積み荷役時に比 ベ，ベント管下とポンプ室が高い值となっている. 居住区域は低い值である.

\subsection{3揚げ荷作業中の環境濃度}

ベンゼンの陸揚げ中荷揚げ当該タンク以外の夕 ンクで発生したガスはベント管から排出される。 揚げ荷の最終段階でタンク内の液面監視はタンク ハッチを開け，目視によって行われることが多い. その際，タンクからガスの放出が起こる。その後 本船の主ポンプによって陸揚げしきれないべルマ ウスより下位のベンゼン及び荷揚げ管系に残留し 


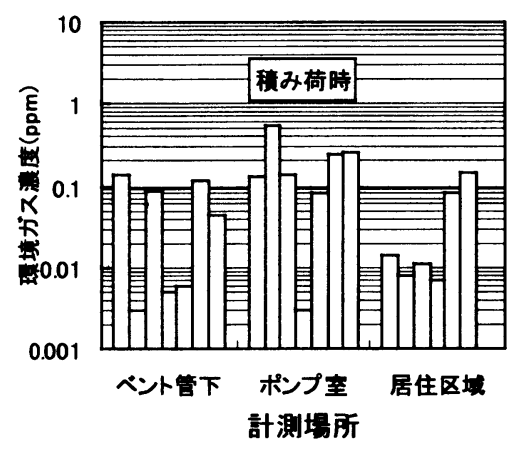

（a）積み荷時環境濃度

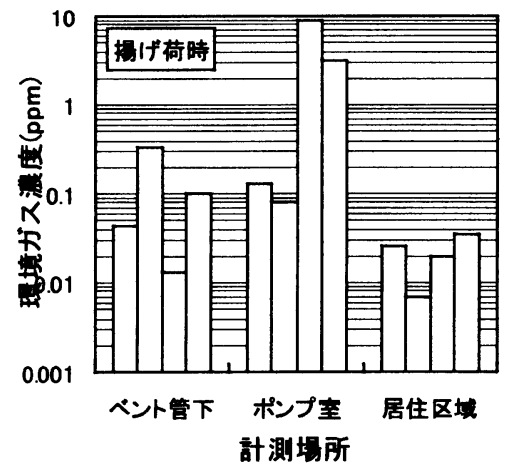

（c）揚げ荷時環境濃度

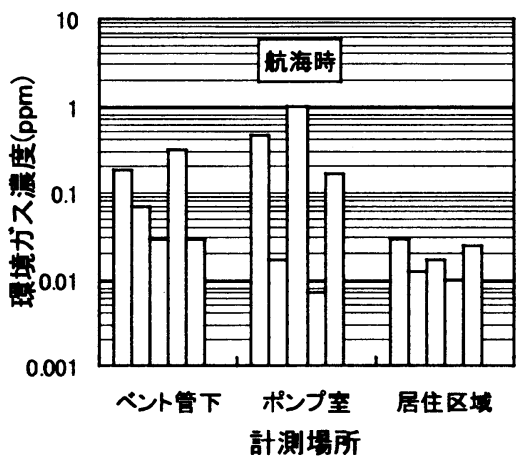

(b) 航海時環境濃度

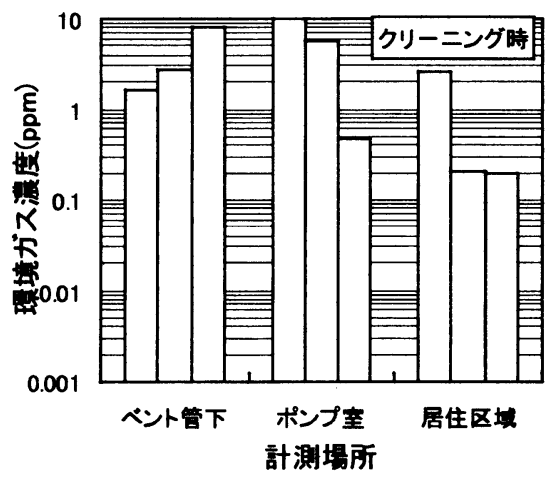

(d) タンククリーニング時環境濃度

図4作業形態ごとの環境濃度

たベンゼンはストリッピングポンプによって浚え が行われる。浚え後配管系に残ったべンゼンは乗 組員のマニュアル作業によってドレンされる. 荷 揚げ中，ポンプシール部，弁，フランジ等配管系 からの漏出が推測される。.また荷揚げ終了後, 陸 側のローディングアームと船側のマニホールドを 切り離す際，管系に残留した少量のベンゼンが漏 れガス拡散が起こる。

揚げ荷役中の環境濃度を图4(c)に示す。ベント 管下とポンプ室が高く, 居住区域は岸壁の濃度 （0.01ppm 程度かそれ以下）に近い值であった。

ベンゼンの陸揚げ中ポンプ等の揚げ荷管系機器 からのガス漏洩が起こりやすく, これらの機器が 集中しているポンプ室が高浱度になるが, ガス漏 洩が少なければ特に高濃度とはならない。

\subsection{4 タンククリーニング作業中の環境濃度}

荷揚げ後の残留貨物と次に新しく積み込まれる 貨物とのコンタミ等を避けるため, 揚げ地から積 み地への航海中にタンク打よび配管系の浚えが行 われた後, 要求されるレべルまで, 水洗浄後に通 風乾燥によりクリーニングされる. タンククリー ニングは通常航行しながら行われ, 通風中に発生 した高濃度のガスはベント管やタンクハッチから 長時間にわたり大気中に排出される。

クリーニング時の環境濃度を図4(d)に示す. 居 住区を除きべンゼン濃度が1 ppm以上と他の作業形 態に比べて高い值となっている。 また, 居住区で もべンゼンガス濃度が比較的高いのは, そこがガ スの排出口であるべント管及びタンクハッチより も風下に位置するためと考えられる。 


\section{3 計測時間}

作業中にガス採取を行ったため，作業時間と環 境濃度の計測時間は同じとなる。つまり困 5 は 4 作 業での船ごとの計測時間を棒グラフで示すが，乗 組員の各作業区分での曝露時間をも表している. どの作業も船ごとの曝露時間に大きな違いはなく 数時間内で終了するが, 一日以上航海が続く船も ある. 4 作業の曝露時間の平均值は平均と表示さ れ，1170分（0.81日）であった。

\section{4 平均環境濃度}

ベント管下, ポンプ室, 居住区域での時間荷重 平均ガス濃度の各作業に打ける算術平均濃度を図 $6(\mathrm{a}) に ， ま た ， 3$ 場所における 4 作業算術平均濃度

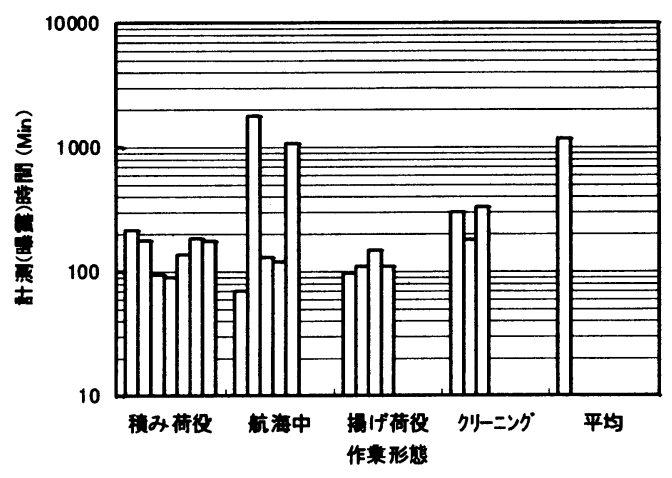

図5 計測 (曝露) 時間

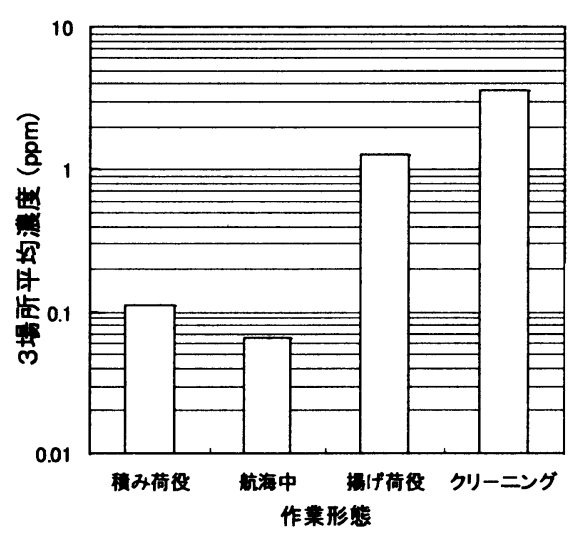

(a) 3 場所平均濃度
および，3場所 4 作業算術平均濃度を図6(b)に示 す.クリーニング中が最も高く $3 \mathrm{ppm}$ 超えてお り，揚げ荷役中がこれに続いている．航海中，積 み荷役中は $0.1 \mathrm{ppm}$ 程度以下の低い濃度となってい る。また，ポンプ室が最も高く $2 \mathrm{ppm}$ を超えてお り, 居住区域は0.3ppmと低い濃度である。クリー ニング作業中の高濃度とポンプ室の機械類からの ガスの漏洩・排出のため 4 作業, 3 場所での平均濃 度は1.3ppmで, 保護具装着濃度と同程度である。

\section{6. リスク解析}

ベンゼン輸送中の船上で, ベンゼンガスに曝露 される乗組員の健康被害の影響を, 発ガンリスク から評価する。ここでリスクは「どうしても避け たいことの発生確率」と定義され, どうしても避 けたいことを「発ガン」とした。モニタリングに よって得られた環境濃度で乗組員は曝露され, 曝 露時間は計測時間に一致するとして評価した。乗 組員が呼吸し, 発ガン性ベンゼンガスに曝露され ることにより追加される発ガンリスクを, 量一反 応関係で無しきい值抢よび直線モデルを用い, 発 ガンリスクの上限を推定する次の関係 ${ }^{(3)}$ から求めた。

$$
\begin{aligned}
& \mathrm{PC}=\mathrm{UR} \times \mathrm{C} \\
& \text { ここでPC : : 生涯発ガンリスク } \\
& \mathrm{UR}: \text { ユニットリスク }\left[\mathrm{m}^{3} / \mu \mathrm{g}\right] \\
& \mathrm{C}: \text { 生涯平均暴露濃度 }\left[\mu \mathrm{g} / \mathrm{m}^{3}\right]
\end{aligned}
$$

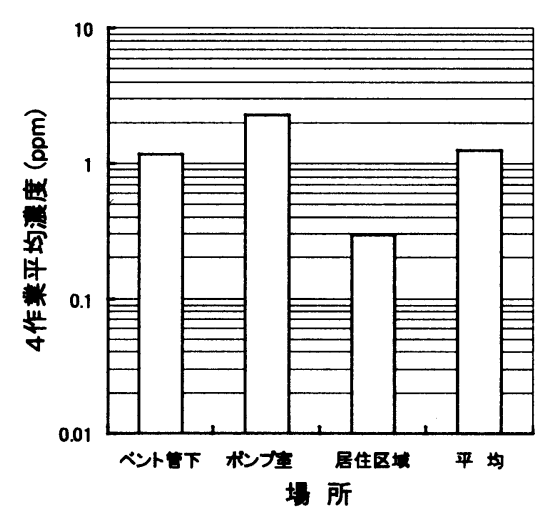

(b) 4 作業平均濃度

図6 平均環境濃度 
ベンゼンのユニットリスクは $2.2 \times 10^{-6} \sim 7.8 \times$ $10^{-6}\left(\mathrm{~m}^{3} / \mu \mathrm{g}\right)$ であることが示されており ${ }^{(4)}$, 平均 值の $5 \times 10^{-6}\left(\mathrm{~m}^{3} / \mu \mathrm{g}\right)$ を用いる. 生涯平均暴露濃 度は次のようにして求めた。生涯曝露時間はNTと なる（N:生涯輸送従事回数 $\mathrm{T}$ :輸送あたりの曝露 時間[day])。従って生涯曝露量はNTCoである， $\mathrm{C}_{0}$ は積み荷役，航海，揚げ荷役，タンククリーニン グの1輸送の間，船内で作業する乗組員の曝露濃 度であり，生涯を 70 年とすれば $\mathrm{C}=\mathrm{NTC} / \mathrm{o} / 70 \times 365$ となる。以上の関係を用い，5，4で求めた平均濃 度 $1.3 \mathrm{ppm}\left(=4.2 \times 10^{3} \mu \mathrm{g} / \mathrm{m}^{3}\right)$ に曝露される乗組員 に対し，輸送あたりの曝露時間を 5.3 で求めた垁 船での運行実績より 0.81 日にとり, 乗組員のベン ゼン輸送従事回数と発ガンリスクとの関係を求め れば罒7の「装着なし(1.3ppm)」が得られる。輸送 従事回数が増えれば発ガンリスクは増加すること が示されている。発ガンリスクは曝露濃度のみな らず, 輸送あたりの曝露時間や輸送回数によって 変化し, 平均濃度より高曝露濃度の乗組員の場合 には輸送回数を少なくすることによりリスクを抑 制でき，また低曝露濃度でも輸送回数が増大すれ ばリスクは大きくなる ${ }^{(5)}{ }^{(6)}$.

$10^{-6}$ の発ガンリスクが一般的に認められる許容 值とされている。この值は 70 年の生涯に 100 万人 に1人の割合で発ガンすることを示している。平均 曝露濃度の乗組員のベンゼン輸送に伴う発ガンリ スクを一般人並にするには，生涯輸送従事回数を 数回程度以下にする必要があることになる．職業 的曝露は一般集団を対象としたものより大きい值 が適用されて打り，0.001程度とされている ${ }^{(7)}$.こ のリスクに対応する輸送回数は 1000 回をやや超え る程度となる，乗組員の健康被害の大きさは乗組

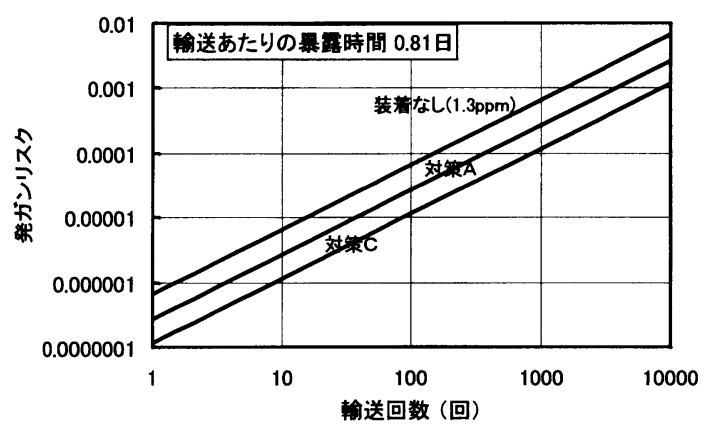

図7 発ガンリスク
員の曝露濃度とともに船上での作業方法, 作業時 間, 輸送従事回数等によって大きく変わると推定 され，許容すべきリスク值が定められれば，これ らの条件によっても許容リスク值内にコントロー ルすることが可能となる.

リスク評価は個人差の無視, 曝露の単純算術処 理などいくつかの仮定に基づいて行われており， 得られたリスク值にはかなりの不確実性を伴って いる.

\section{7. 対 策}

乗組員のガス曝露を少なくする方法には, 発生 源対策と影響緩和策が考えられる。発生源対策で はガス発生・排出を抑制して環境濃度を低下させ， 影響緩和策は乗組員の曝露機会を少なくする方法 である。ここでは最も簡易な影響緩和策である， 作業中に保護具装着の効果を検討した。高環境濃 度となる作業形態抢よび作業場所で呼吸具を装着 する次の対策を想定した。

対策A：クリーニング時居住区以外での作業中 には呼吸具を装着する

対策B：ポンプ室での作業中にはすべての作業 形態で呼吸具を装着する

対策 $\mathrm{C}$ ：対策 $\mathrm{A}$ と対策 $\mathrm{B}$ をわせて行う

呼吸具装着の効果を $90 \%$ (乗組員は環境ガス濃 度の $10 \%$ に曝露される）として評価した 4 作業平均 濃度を図8に示す。対策時の推定濃度は対策Aでは $0.53 \mathrm{ppm}$, 対策 Bでは $0.57 \mathrm{ppm}$, 対策 Cでは $0.23 \mathrm{ppm}$ が得られる。呼吸具を装着しない時が 1.3ppmであるので対策Aまたは対策Bでは約 $40 \% の$ 曝露濃度になると推定され, 対策 $\mathrm{C}$ を行うことに より約 $20 \%$ とり, 作業中呼吸具を装着する効果 の大きいことが示されている。

呼吸具装着の効果を定量的に評価した結果は四7 に示され，大きなリスク削減となって現れ，リス ク削減の有効な手段である。

\section{8. まとめ}

船上のベンゼン環境ガス濃度を把握し, データ に基づいた乗組員の健康リスク評価とリスク削減 の検討を行い, 以下の結果を得た。 
1）輸送中の平均環境濃度は許容作業限界濃度に近 い値と推定された。ただし，個人の曝露は作業 方法，作業時間，作業場所等により相当の幅を 持っているものと考えられる.

2）積み荷役，航海中では濃度の推定值が呼吸具装 着勧告值 $(8$ 時間TWA-1ppm)を下回っている ことから，人の健康に影響を及ぼしている可能 性は小さいと考えられる.

3）揚げ荷役，タンククリーニングにおいては，濃 度の推定值が勧告值と同程度以上となることが あり得ることから，作業時には呼吸具を装着す るか，環境中の濃度の低減を図る必要がある。

4）ベンゼン輸送中の乗組員の健康リスクは環境濃 度, 輸送あたりの曝露時間, 生涯輸送従事回数 によって影響され，これらを適切に組み合わせ ることによりリスクの大きさをコントロールで きる。

5）クリーニング時やポンプ室での作業時に呼吸具 装着の効果の大きいことが示された.

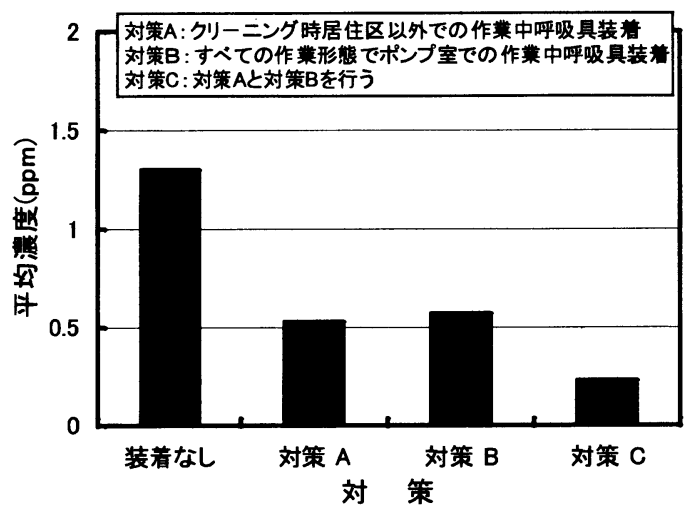

図8 呼吸具装着の効果

\section{9. 謝 辞}

本研究を実施するにあたり乗組員，荷役関係者， 運行関係者，その他多くの方々の協力を得た。協 力いただいたみなさまに感謝いたします。

\section{文献}

(1) 間島, 山口, 藤井, 山之内, 坂本, 日本航海学会論文 集 99号(1998)，91.

（2）環境庁大気保全局，「有害大気污染物質測定マニュアル」 平成 9 年

（3）例えば平石次郎ほか訳編，「リスクアセスメントハンド ブック」 (1998年), 丸善株式会社

(4) EPA IRIS Substance file-Benzene; CASRN 71-43-2 $(10 / 16 / 1998)$

(5) 山口, 藤井, 間島, 山之内, 坂本, 日本航海学会論文 集 102号, (1999).

(6) 山口, 藤井, 間島, 山之内, 坂本, 日本労働衛生工学 会講演抄録集 BK-34, 172(1999-11).

（7）J.V.ロドリックス著 宮本純之訳，「危険は予測できる 加(1994年), 化学同人社 